\title{
Emplacement Sequence in X-Ray Pipe, Attawapiskat Kimberlites, Ontario, Canada
}

\author{
Alexandrina V. Fulop ${ }^{1,2}$, Nathalie S. Lefebvre ${ }^{1}$, Stephan Kurszlaukis ${ }^{1}$ \\ ${ }^{I}$ De Beers Canada Inc., Toronto, Canada \\ ${ }^{2}$ North University, Baia Mare, Romania
}

\section{Introduction}

The Jurassic aged X-Ray kimberlite pipe is part of the Attawapiskat Kimberlite Field, Northern Ontario, Canada. It is composed of four discrete volcaniclastic kimberlite units, identified by detailed logging of ten diamond drill core holes (2126 $\mathrm{m}$ total length) and confirmed by petrographic and geochemical investigations (Fig. 1).

In plan view the pipe has an ellipsoidal shape measuring about $260 \mathrm{~m}$ by $170 \mathrm{~m}$. The pipe walls dip steeply towards the West, North-West and South-West and slope gently towards the South. The country rock hosting X-ray is represented by Ordovician to Lower Silurian limestone. The present day thickness of the limestone is about $300 \mathrm{~m}$, and about $200 \mathrm{~m}$ is thought to have been eroded since emplacement (F. Brunton, pers. comm. 2007). Basement rocks underlying the limestone sequence do not commonly occur as xenoliths within the pipe.

The four volcaniclastic units were defined based on compositional parameters, geometry, contact relationships and sedimentary structures which record the depositional physical processes enabling reconstruction of the facies architecture of the pipe.

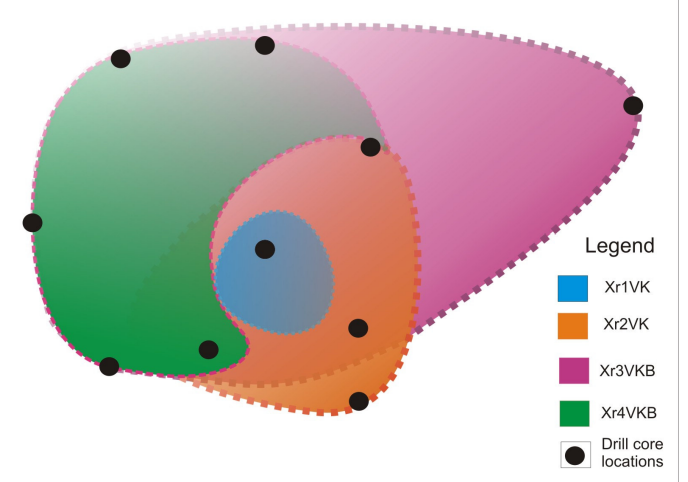

Figure 1: Distribution of the volcaniclastic kimberlite units within X-Ray pipe.

The nature of pyroclasts can give information about the style of eruption. The presence of accretionary lapilli suggests the existence of moisture in the eruptive system and thus the thermohydraulic interaction of kimberlite magma with meteoric water. These thermohydraulic explosions are highly energetic and explain also the high abundance of country rock xenoliths down to small particle sizes. The sedimentary structures of the volcaniclastic deposits give valuable information on the conditions of sedimentation or resedimentation. Irrespective of the limitations of such investigations in drill core, some observations such as a massive versus bedded or crudely bedded structure have implications on the dynamics of the eruption and the style of deposition. Other observations such as the presence of soft sediment deformational structures indicate the deposition in a wet environment.

The geometry of the volcaniclastic units allows to conclude on the position and volume of depositional units within the pipe. Judging from the internal structure of a unit (massive or bedded) and changes in its lateral and vertical granularity, conclusions on the position of a feeder vent can be drawn.

Concordant and discordant contact relationships between the units are essential with respect to understanding the growth of the pipe as they show the units succeeded in time and space.

Building up the facies architecture of the pipe is therefore a complex process which reflects the ongoing sequence of pipe excavating, infilling and modifying events.

\section{Facies architecture of X-Ray pipe}

$\mathrm{X}$-Ray pipe composes four distinct geological units of volcaniclastic origin. Three of these units are products of successive major explosive events (from oldest to youngest): Xr3VK, Xr2VK and Xr1VK. The fourth unit, $\mathrm{Xr} 4 \mathrm{VK}$, is a composite unit consisting of mixing products from $\mathrm{Xr} 3 \mathrm{VK}$ and $\mathrm{Xr} 2 \mathrm{VK}$ on a grain by grain basis formed during a complex resedimentation event. $\mathrm{Xr} 4 \mathrm{VK}$ is older than $\mathrm{Xr1VK}$.

The oldest unit, Xr3VK extends at surface towards the East and the North-East (Fig. 1) and downwards to an unknown depth. It is described as a heterogeneous lapilli tuff (Fig. 2) grading into a massive xenolith-rich breccia with depth (Fig. 3). The presence of relatively abundant accretionary lapilli, as well as the abundance of country rock xenoliths down to small particle sizes suggest a phreatomagmatic eruption mechanism.

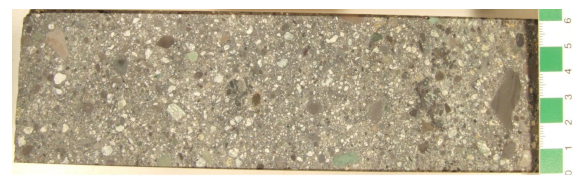

Figure 2:

Slab photo of heterogeneous lapilli tuff from Xr3VK. 


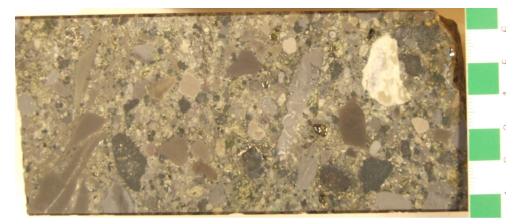

Figure 3:

Slab photo of xenolith-rich breccia from Xr3VK.

The internal structure of XrVK3 shows two zones with different grain sizes: the fine-grained zone occurs at the top of the unit and grades with depth into a coarsegrained breccia zone. Overall, the unit displays a normal coarse tail grading.

The dominant sedimentary structure is massive, with crude bedding defined by slight fluctuations of olivine grain size and abundance. The fine-grained zone is matrix-supported and loosely-packed while the breccia zone is clast-supported and loosely to closely-packed.

$\mathrm{Xr} 3 \mathrm{VK}$ is interpreted to represent either primary deposits emplaced by pyroclastic density currents where the lower breccia zone is deposited "en masse" and the upper fine-grained zone by rapid deposition from fallout (Druitt, 1998, Freundt and Bursik, 1998) or deposits resedimented from the unconsolidated tephra ring onto the crater floor (Lorenz and Kurszlaukis, 2007). The olivine grain size fluctuations may be attributed to pulses of the eruption column.

The geometry of Xr3VK shows deposits thickening towards the North and thinning towards the South in the examined drill cores.

$X r 2 V K$, the second oldest unit in the succession is located in the central south-eastern part of the pipe, on top of $\mathrm{Xr} 3 \mathrm{VK}$ (Fig. 1).The unit is relatively very rich in olivine (average 40-45\%); the country rock xenoliths are overall low in abundance (average 7-10\%) and belong to a relatively narrow range of limestone lithologies. Classified as a heterogeneous lapilli tuff, (Fig. 4) Xr2VK deposits can be more likely attributed to magmatic eruptions than to a phreatomagmatic event, which is supported by the scarce accretionary lapilli.

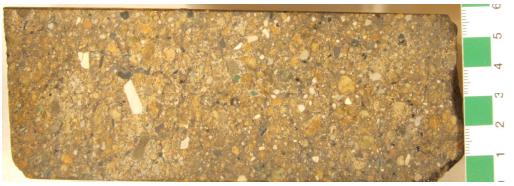

Figure 4:

Slab photo of

heterogeneous

lapilli tuff from

$\mathrm{Xr} 2 \mathrm{VK}$.

The internal structure of the unit is defined by a change in olivine grain size exhibiting a fine-grained upper portion and a lower coarse-grained portion. Deposits are massive with slight grain size fluctuations. The structure is matrix-supported, loosely-packed grading downwards to matrix-supported, closely-packed and clast-supported, loosely-packed. A vague normal coarse tail grading occurs in most of the drill cores.

Xr2VK suggests the emplacement from pyroclastic density currents, a combination of "en masse" emplacement and gravitational settlement in the proximal facies or the proximal resedimentation by mass flows (Druitt, 1998, Freundt and Bursik, 1998), without any effective separation on size fractions. A primary pyroclastic origin is believed to be more likely than resedimented tephra.
The indistinct grain size fluctuations suggest a pulsating eruption column.

The geometry of $\mathrm{Xr} 2 \mathrm{VK}$ shows thickening towards the South and thinning towards the North, East and West. Single beds are steeply thinning towards the NorthEast, in accordance with the absence of the lower, coarser facies.

The contact relationships between $\mathrm{Xr} 2 \mathrm{VK}$ and $\mathrm{Xr} 3 \mathrm{VK}$ are key features in the evolution of the pipe. Overall, the interfaces between the units are gradational. However, there is evidence that both units also mixed due to resedimentation events, forming a new unit, $\mathrm{Xr} 4 \mathrm{VK}$.

$\mathrm{Xr} 4 V K$ is the third unit in the chronological succession of emplacement. It fills the western part of the pipe (Fig. 1) during a complex depositional episode following the second explosive event that produced Xr2VK.

Petrographically, Xr4VK shows different degrees of mixing between $\mathrm{Xr} 2 \mathrm{VK}$ and $\mathrm{Xr} 3 \mathrm{VK}$ : an intimate mechanical mixing, grain by grain, was identified in the lower half of Xr4VK (Fig. 5). Interlayers of Xr2VK and $\mathrm{Xr} 3 \mathrm{VK}$, several meters thick, occur in the upper half of the unit and small blocks ( $\mathrm{cm}$ to $\mathrm{dm}$ in size, with sharp and angular contact limits) of semiconsolidated volcaniclastics belonging to both units were recognized on top. $\mathrm{Xr} 3 \mathrm{VK}$ is the dominant component of Xr4VK towards the North and the North-East. Towards the South and the South-East, $\mathrm{Xr} 4 \mathrm{VK}$ is dominantly composed of $\mathrm{Xr} 2 \mathrm{VK}$.

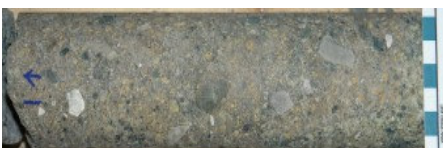

Figure 5: Drill core photo of $\mathrm{Xr} 4 \mathrm{VK}$ consisting of grain by grain mixing of $\mathrm{Xr} 2 \mathrm{VK}$ and $\mathrm{Xr} 3 \mathrm{VK}$.

The internal structure of $\mathrm{Xr} 4 \mathrm{VK}$ is complex. The country rock xenoliths show a vague normal coarse tail grading. Most of the unit is massive, sometimes with crude bedding or bedding represented by interlayered $\mathrm{Xr} 3 \mathrm{VK}$ and Xr2VK layers. The deposition of Xr4VK was probably triggered by the partial resedimentation of mostly unconsolidated volcaniclastics belonging to $\mathrm{Xr} 3 \mathrm{VK}$ and $\mathrm{Xr} 2 \mathrm{VK}$, successively entrained "en masse" and by slides/slumps in a semi-consolidated state. The mass movement of the volcaniclastic piles, as well as the gravity-driven failure of country rock blocks was likely induced by subsidence or by the shocks and tremors following the second explosion.

The geometry of Xr4VK shows thick deposits emplaced in the West, with gradational contacts with Xr3VK towards the North and the North-East and with $\mathrm{Xr} 2 \mathrm{VK}$, towards the South and the South-East.

$X r l V K$ is the youngest unit in the succession, produced by a third major volcanic explosion. The unit is emplaced on top of $\mathrm{Xr} 2 \mathrm{VK}$, in the central-south eastern part of the pipe (Fig. 1).

Xr1VK consists of relatively abundant juvenile pyroclasts (average 2-3\%), both clastic and coherenttextured (Webb et al., 2006). Accretionary lapilli are comparatively abundant and show complex internal structures (Lefebvre et al., 2008). The rock is classified as a heterogeneous lapilli tuff (Fig. 6). 


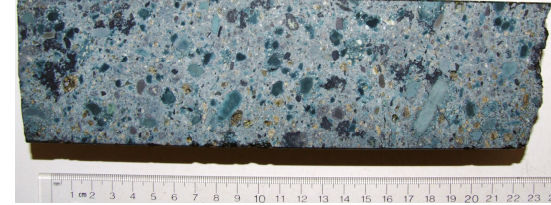

Figure 6: Slab

photo of

heterogeneous

lapilli tuff from

Xr1VK.

The sedimentary structures identified in drill cores show two facies corresponding to the thick and the thin sequence of the deposit, respectively: the thick sequence extends to an unknown depth comprising massive deposits which are matrix-supported, looselyto closely-packed and show crude bedding defined by olivine grain size fluctuations. The thin sequence occurs in the western part of the pipe and shows bedding with two different zones dominated by fine ash and medium-grained olivine respectively, grading into each other. The massive facies is consistent with proximal, intra-vent mass flows/pyroclastic density currents which record the pulses of the collapsing eruption column. Xr1VK contains rare, discontinuous fine and coarse ash layers consisting of abundant accretionary lapilli as well as a thin sequence of ash layers, all of them showing deformations in a semisolid state. The softly deformed tuffaceous clasts suggest an origin from crater-lake deposits incorporated/recycled either during the explosive eruption column cutting through the crater-lake or during the emplacement of the pyroclastic density currents onto the floor of the crater-lake. The lateral bedded facies represents a sequence of thin flow units which might have undergone flow separation due to water or air entrainment or a sequence of fallout or surge deposits. The lateral change from massive to bedded deposits shows also a distinct decrease in thickness which may be related to the pre-existing topography of the earlier crater floor.

The geometry of the thick, massive sequence of Xr1VK cutting through earlier pipe-filling units corresponds to intra-vent deposits bordered westwards by remnants of the bedded crater rim.

Xr1VK shows gradational contact relationships with $\mathrm{Xr} 2 \mathrm{VK}$.

\section{Conclusions}

X-ray pipe consists of four distinct volcaniclastic kimberlite units. Drill core analysis allows the reconstruction of the pipe's internal architecture revealing the emplacement sequence of the units.

The pipe was excavated during a major phreatomagmatic event followed by the deposition of $\mathrm{Xr} 3 \mathrm{VK}$ onto the crater floor. Xr3VK reflects either primary deposits emplaced from pyroclastic density currents or volcaniclastic deposits resedimented by mass flows of pyroclastic material from the crater rim. The second volcanic event was dominated by magmatic explosions which deposited $\mathrm{Xr} 2 \mathrm{VK}$ on top of $\mathrm{Xr} 3 \mathrm{VK}$, probably as primary deposits emplaced by pyroclastic density currents.

The next event contributing to the pipe infill was exclusively re-depositional. Xr4VK was emplaced in the western part of the pipe as a mixed unit, resedimenting parts of unconsolidated or semi-solid
Xr3VK and Xr2VK by mass flows and mass movements, respectively.

The third and the last major explosive event was phreatomagmatic and likely transected a crater lake. Most of Xr1VK was emplaced intra-vent by proximal pyroclastic density currents. The vent migrated slightly from the second to the third explosive eruption, probably from the South or South-East towards the centre of the pipe, as shown by the geometry and the internal structure of Xr2VK and Xr1VK units (see also Ort and Carrasco, 2004).

X-ray pipe was formed and filled during three depositional events triggered by eruptive processes and one event formed as the mechanical response to gravity-induced subsidence or equilibration after the eruption (Suhr et al., 2006). Phreatomagmatic and magmatic explosions as well as gravitational resedimentation processes all worked together within a relatively small crater, either synchronously or in a slight time sequence.

Understanding the sedimentation and distribution of volcaniclastics within the pipe is very important due to the potential variability in diamond grade of the different depositional units.

\section{References}

Druitt, T.H., 1998. Pyroclastic density currents, in Gilbert J.S.O Sparks, R.S.J. (eds) "The Physics of Explosive Volcanic Eruptions", Geological Society, London, Spec. Publ., 145, pp. 145-182.

Freundt, A., Bursik, M.I., 1998. Pyroclastic flow transport mechanisms, In Freundt, A. and Rosi, M. (Eds.): From magma to tephra-modelling physical processes of explosive volcanic eruptions, Developments in volcanology 4, pp. 173245.

Lefebvre, N.S., Fulop, A.V., Kurszlaukis, S., 2008. Variance in Juvenile Accretionary Pyroclasts of the Attawapiskat Kimberlites: Implications for Eruption Dynamics and Interpretation of Volcanic Processes from Drill Core. $9^{\text {th }}$ International Kimberlite Conference Proceedings, Frankfurt, Germany.

Lorenz, V., Kurszlaukis, S., 2007. Root zone processes in the phreatomagmatic pipe emplacement model and consequences for the evolution of maar-diatreme volcanoes, Journal of Volcanology and Geothermal Research, 159, pp. 4-32.

Ort, M.H., Carrasco-Nunez, G., 2004. Vent alignments at maar volcanoes. Second International Maar Conference, Abstract Volume, p. 82, Budapest.

Suhr, P., Goth, K., Lorenz, V., Suhr, S., 2006. Long lasting subsidence and deformation in and above maar-diatreme volcanoes - a never ending story. Zeitschrift der Deutschen Gesellschaft fuer Geowissenschaften, 157/3, pp. 491-511.

Webb, K.J., 2006. Juvenile clasts in kimberlite: standardized comprehensive description towards unravelling emplacement mechanisms. In: B.H. Scott-Smith (Ed.), Kimberlite Emplacement Workshop, Saskatoon, Canada.

Contact: A.V. Fulop

alexandrinafulop@yahoo.com 